
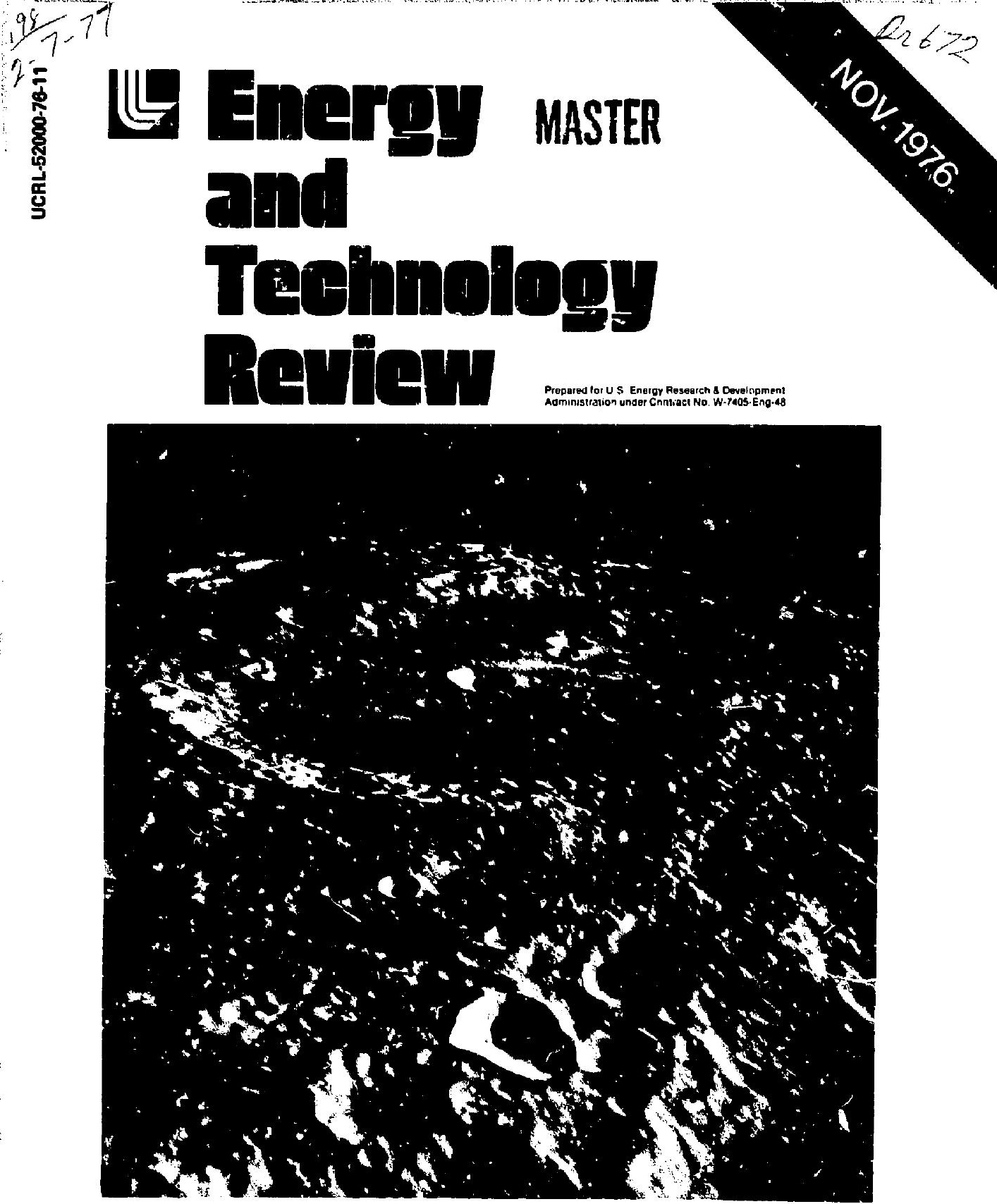
Mollie

Thes report wos preposed as an decisunt ni wirk sponsimed hy the linuted Stales cioverniffent Noither the United Siotes nur the United States Fnergy Kesearch \& lievelupmerit admonixtestion. niue atly of thetr employes, nur any rif their cuntractots. vuheonteaclors. ilt their emplistes. makey uny warraniy, "xmess or implied, at axumes any lecal lability ar tesponsitiluty for the accurscy. completeness an uselulness is any

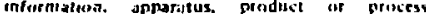
disclused. or repeesents ihot its use withla nut infringer primately nutard rights

\section{NOSIL"F}

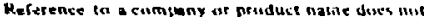
inply approual is recommendatuon of the pradurt by the Unoversily of Califormu ar the I 5 I nerg) Kesemech \& Irevelupment Aumitistiation to the exclusum of thers thot may ho witubly

Prof a in the United States of Americ. Aratiate frum

Nituons: Technical Infermaturu Serwice

U.S. Departinent of ciummetce 5285 Port Royal Rosut

Springtirld. Yiegsia $2216 \mathrm{I}$

Price Bunted conys Slisriotiche 12.25

\begin{tabular}{|c|c|}
\hline lape Kungs & $\begin{array}{l}\text { Domestit } \\
\text { Price }\end{array}$ \\
\hline $\begin{array}{l}001.025 \\
026.050\end{array}$ & $\begin{array}{l}\$ 1.50 \\
\$ 4.00\end{array}$ \\
\hline
\end{tabular}




\section{ABOUT THE COVER}

Surliste features on the fat side of Ho M/un as seten from orbit. Mapenetic field meisurements were taken from orbit and on the sutfate ta determinte the electrical conductivities of desply buried layers of rock. Hewever, internal lemperatures derised from the contductivities contlicted violently with salues frem other, usually reliable methods of estimating lac sub. surfate tempetatures. Indepondent of this problem, LLL gecophysicists discoveted a serions experintental ctory in former methods of meas. uring ils electrical sonductivities of minerals under extreme tem. peratures and pressures. Whith their datention was fexused on the aloun temperature disagreenent. they re. solved the discrepancy. shedding sume new insights on the structures and histories of bollt the Mon and the barth. (NASA photo. Lunar Sticnic Institute, Ilouston. Texas.)
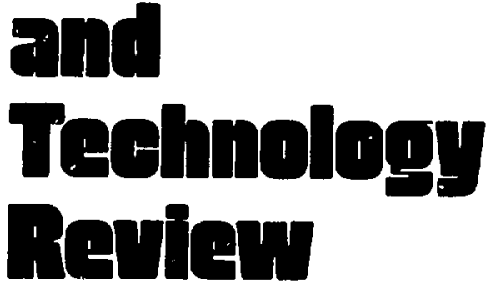

Stientific Lidifor: Hobert W. Selden

Genesal Editors: Hichand B. Crawford hellt L. Cunnuings

Briaıl D. Jarman

Judyth K. Prono

\section{BAIEFS}

\section{SCIENCE AND TECHNOLOGY}

Taking the Moon's Internal Temperature

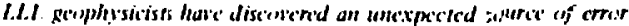
in provieus methads of meosuring the electrical comdectirities of mineruis. This relcourch has reseh'ed a scrions discrepancy in the

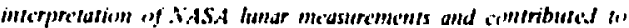
osher t.aburatury pnigrams.

Recognizing the Pattern of Crime

We are working with the Sun Dege Police Deparme'ls to apply

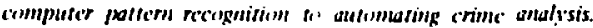

\section{ENVIRONMENT, HEALTH AND SAFETY}

\section{Gatting the Facts About Ozone}

Our Suftllise' Ozenc' Andlesis Cemer will te assimilating the flord

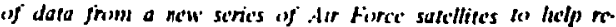
scarthers unned the complex metwork of reactions that main. fains the tiarth's protective asme blanket.

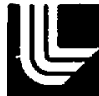

LAMIENCE LPEAMOARE LABORATOTY

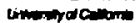

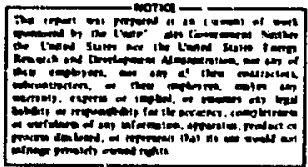




\section{Briefs:}

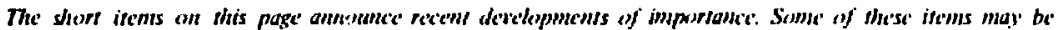
amplified in fusure issues. noun of this moterial is reforred elsewhen' in this issuc.

\section{CONSTRUCTION EEGINS ON FUSION RESEARCH FACILITY}

Construction has hegun at LLL on a tactility fiot studying how highenergy neturons produced in pusion power reactors my affect vital reactor components. such as vacuum vessels, insulators, and mjggels. Known as the Rolating Tutget Neutron Source (RTNS). this 55 milliun. I $600 \cdot 17^{2}$ fatility is sclieduled 14 begin operation in Mocil 1978. It will be avajlable under LEDA auspices to reseatiliets frotin arcound the world for experiments stucial to the engineeting designt of protentype fusion pouner plants.

Reseatclets will expose small somples af metals to 14.MeV neutron hembarditiet one fifth as intense as that expected in proposed fusion rejtitots. (Fissinn reactors are expected to produce about 50 trillitu iH.MeV neutrons per square centintetre pet sciond. I Metals in be tested range from stainless steel. J steuctural material. to superconducting alloys of niobjum and tin. Future magnetic fusion porter plants are alntost certain to require supereonducting magnets (1) minisnire electrical consusuption.
Arter expossute, the samples will be examined tor weakening. embtittlement. blistering from lielium bubble fonustion, and in the cuse of the superconductors changes in condlictivity. Such effects afe inportiont in fusion reacter design because of their potential impact on the longevity of purts.

The RTNS fasilit) will replace a similar but smaller cesearch liscitity at Livermene that for the pase 10 years has provided highenergy neutrons st aheout one-fiticth the intensity of proposed fusion rejitors. Buth facilitios ate based on a rotaling torgel contept for producing an intense flux of fession neuteons. A narrow stream of douscrium bounbards a haghapeed rolating target contianing tritium: the D.T teac/un produces 14-AteV neutsums. The tatget spins and wobhirs to vory the impatt posint of the detterium bean. Whitit otherwise would heat the latget entugh to release the tritium. The tafget is wider-cosoled.

In addition to this neutron source. the new facility will conlsin apparatus to irradiate tejcler materials with cliarged particles and $x$ rays. atluwing researchers (1) miestigate the cumbined effects of a variety of fusion reaction products. 
LLL geuphysicists have been instrumental in resolving a serious discrepancy between lunar magnetic-ficld dala and melting studies of luriar basalts brought back Irom the Moon by Apollo astronauts. Estimates of the subsurface temperatures, based on lunar electrical conductivity measurements and laburatory experiments, were hundreds of degrees below those given by models using known melting points of various minerals. Our work uncoversd a basic naw in previous measurcments. New measurements under more ralistic conditions brought the clectrical-conductivity temperature estimates inla apeement with temperatures derised from melting experiments. This same wark has also contributed to our in sifi coal gasification studies, to ERDA is dy. hot-rock sothermal effor. and wo our progrem of moniloring for seismic evidence of elandestine nuclear lesting.

Is the interiog of the Moun hot like the barth's interior? How deres the electrical conductivity of the mineral alivinu vary with temperature at pressures to 5 Gib? There is a connection between these two questions: by answering the latter. LLL peoplysicists were able to answer the fomer and resolve a contlict in lunar intemal ienuperature calculations troubling NASA.

The physical properties of rocks and minerals at hiph temperatures and pressures liave long been of interest to the test. seismic monitoring. and energy programs at LLL. Consequently we have extensive capabilitics both for producing extrences of pressure and ienuperature and for nieasuring these properties. There seenied to be no imnediate application for neasuresinents of ti.- electrical propertics of rotks. howerci, and thus support for these measurements received a low priority -- although theoretizal studies continued.

NASA. at the same time. has facing a dilemms. Aning the data brought back frosm the Moon by the Apollo flights were tw's apparent; contradictory nkeasurements frum which junar subsurijace remperatures could be calculated. listimstes based on the melting properties of surface minerals gave a high

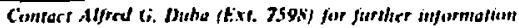
$\mathrm{cm}$ this antirte. value; measurements involving the lunar conductivity variation with depth, the solat wind, and the electric conductivitics of minerals as neasured in the laboratory gave values hundieds of degrees lower.

This was no trivial matter. The subsurface cemperature profile is one of tha prime piercs of evidence in all theories of iiow the Moon was formed. If the melting pint minasurements were right, it would mean revising most of the previaus ideas abuut the Moon's oripin. If the electrical conductivity interpretations were right, there would still be the question of how the melting point estimate could be Si) fat off.

Boh temperature and pressure increase with depth in the Earth and Moon. It is relatively casy to salculaic the pressuse at any depth from the densitics of the overlyung rocks. But temperature is not so easily ascertained. There is no way to probe the region Jirecty: all subsurfoce teniperatures are estinates based. st indirect evidence. Teunpersture is thus one of the major uncertainties in the study of planetary interiors.

NASA's method for inferring the lunat interior teniperature involved measuring the nugnetic field indicied in the Moon by sudden changes in the solar wind. The Moon's semnant ficld is very weak and varics greally fo din place to place. To nonitor the mognetic field. the astrom uts set up a series of flux.gate magnetometers (Fig. I) at the various landing sites. Comiparing the readings from these magneloneters with those of magnetometers in orbit around the Moon produced a collerent picture of the magnetic field's respunse to changes in the solar wind. These responses. in tusn. could be interpreted to delermine the conductivity of the menderiying rocks.

Although most rocks are good insulators at room temperature (especially when they are very dry, as they are on the Moun), thej clectrical conductivities depend strongly on the temperature. In some tases the conductivity may increase mose than a trillion-fold between roont teniperature and $1000^{\circ} \mathrm{C}$. Hence the clectrical senductivity of a dry rock sliould be a sensitive inticator of its temperature.

This temuperattice scale must first be calibrated. however, to be useful. For calibration. specimens of the appropriate minetals must be obiained. subjected to extreme temperatures and pressures. and their 
conductivities measured. To the extent that laboratory conditions duplicate the conditions in the interior of the Moon. such measurenents should produce an accurate temperature scale.

According to the best present information. the outer $400 \mathrm{~km}$ of the Earth and the butk of the Moon consist of two minerals: olivine and pyroxenc. Olivine predominates in the Earth. pyroxene in the Mools. These minersls contain mainly oxygell. silico:, magnesium, and iron. The najor compositional difference hetween them is that pyroxenc contains mote silicon, it proportion wo its oxygen content, than olivin:

When NASA seientists compared the existing laboratory ista on the tempe,ature variation of electrical conductivity for olivine and pyroxene with their data from magnetometer mensurements, their salculations showed temperatures hundreds of degrees below those necessiry to produce the vast lava nows that fill the Moon's great maria plains. If the Moon was ieally hot enough to have produced large amounts of molten ruck. why did the conductivity measurements indicate such low intenor temperatures" Where had the measurements gone wrong?

Meanwhile, independent of the NASA difficulty, LLL geophysicists were beginning to have their doubts about laboratory measurenents of electrial conductivity. They thought of examining the assumption that the laboratory conditions exactly dupiiested subsurface conditions. If this assumptior: were foulty, the conductivity measurements night be in error.

The study's first clue resulted from conductivity measurements on a pair of olivine specimens of apparenuly identical compusition. One came from the San Carlos Indian Reservation in Arizona and the other from St. John's Isiand in the Red Sea. The San Carlos olivine had a thousand times the eonductivity of the Red Sea olivine at the same temperature.

Such a discrepancy clearly indicated that the specimens couldn't be truly identical. There had to be some subtle difference to atcount for the disparity in conductivity.

A careful reanalysis tumed up a possible lead. Although both specinens contained the ssme amisunt

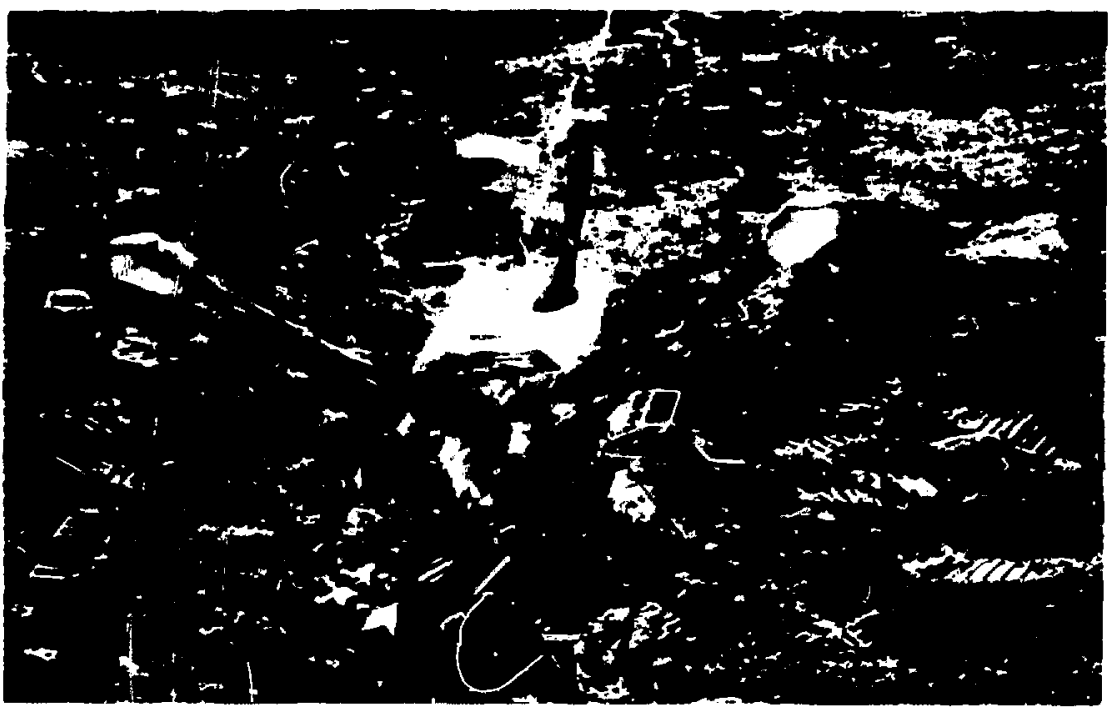

Fy. 1. The nupa warece megetometer deployed at the Apollo 16 landing site. The bool prinb indicate seale. The golden

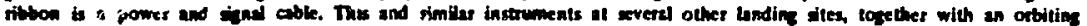

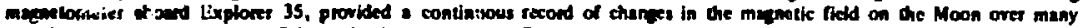
monthe (NASA ploto, Lenst Science Institute, Houston, Texes) 
Fig. 2. Electrical conductivity meanurements on two pecimens of olivine under - variety of circumunces The apecimen Irom St. John's teland in the Red Sea has a conductivity less than a thougand th that of the specimen from the San Carlos Indian Reservation in Arizon when both are measured in utr. Replacing the ait with unon had simost no effect on the San Carlas epecimen. The conductivities apre only when both are measured in a buffering mixture of carten dioxide and carbon monoxide. This buftering mixture controls the oxysen fugacily, imulatine conditions in the deep interior of the Eurth and Moon.

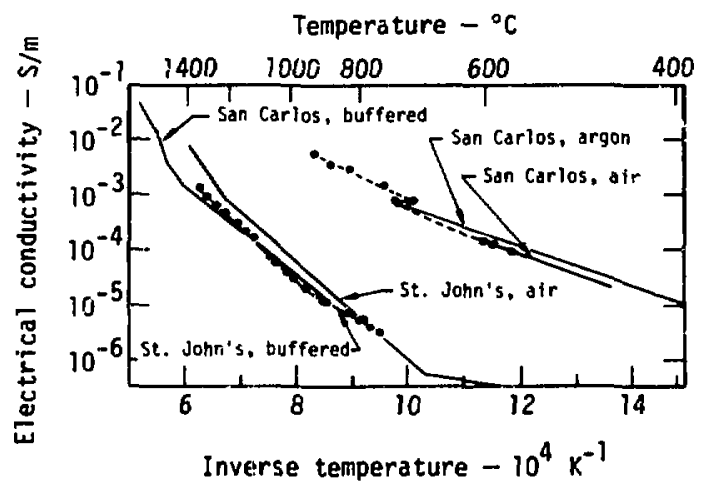

of total iron. about $2 \%$ of the iron atoms in the San Carlos olivine were in the fertic oxidation stats. The Red Ses olivine contained no trace of ferrit iron: all its iron was in the more reduced fersous state.

Once thi: difference in the oljvines had been delected, it was fairly straightforward in deduce the resson for the conductivity diler:ans. The olivine deep underground must contain no ferric it on: the sery exisience of olivine in planetary interiors at $1000^{\circ} \mathrm{C}$ is evider,ce that at tit:t depll the oxygen fugacity fproportionai to oxygen's partial pressure and the eliemical reactivity of oxygen at a given temperature ) is less then one-hunded -millionth of that at the Earth's surface. The Son Carlus olivine specink n (and the vast majorily of other olivine specimens) must have been exposed Io oxycen while it was still ho' enough to oxidize. The gem-quality Red Seit nlivise. on the oiher hand. nust have couled below about $600^{\circ} \mathrm{C}$ before oxygen reached it.

This being the as.. it follows that all previous measurements of olivine conductivity (and, by analogy. that of pyroxene) at kigh tempetatures nitust be in error. because thuy started with partly oxidized material and because they failed to prevent further oxidation during the measurenients. Even neastuemeris cerd!ncted in racuum or in on inert argon atmosphere (which would contain a few parts per million of oxygen as an impurity) would expess the olivine to thousands of tinkes more oxygen than exir's $100 \mathrm{~km}$ underground.

When word of these results reached NASA scient ists, hhey immediately enlisted our help in unravelling their measurement mystery. The objective of our study was to find a vasy to simulate the conditions deep beneath thic lunat surface closely enough to arrive at meaningful electrical condurtivity measurements. Our conductisity uxeasurements were fi concentrate on pyroxene. the major constituint of the lunas inierior.

is hinted above. simply excluding oxygen ussn't gund enough. Going to the othet extreme. that is. attively removing the oxygen, as with a hydrogen iumace. would be just as bad. In a hydrogen furnace the axyenen fugatity is about $10^{-3.5} \mathrm{P}$. Undet these conditions oxygen would leave the olivine and netallic irun would appear, contetely invalidating the conductivity mosusurenents. Furthernore, the right value of tupacity was not a conslant, but changed with the temperature.

The solution was to buffer the oxygen fugacity with a nixture of carben dtoxide and carbon monoxide. With this mixture ihe oxygen fugacity closely followed the olivine stabiltry interval. Neither ferric nor metallic iron was produced regatdless of temperature.

The proof of the pudding cartie in conductivity tneasure;nents on San Carlos olivine using the carbon dioxide/carbon monoxide buffer system. Once the specimen came into equilibriun with the buffer, its conductivity dropped a factor of a thousand and agreed closely with that of the Red Sea olisine uneasured under the same conditions ( $F_{i g}$. 2).

Naturally. the equipment for making thesc conductivity measurements works equally well with other materials. In fact, we have measured conductivitics for pyroxene, gamet, albite, and basalt. 
among others. These rocks and minerds are also present on the Mown and call makic mitor contributions to the overall conductivity.

When our values for the conductivity of tonsr rusks are combined with the NASA magnetumets Jatu. they yicld a temperature profile that agreses substantially. with the values derived from mineral melting points. Figure : compares the resulting selenothem (1) (emperature-ss-depth surve for the Moun) witt: the presious uncetain estunates. The new selenutherm comes slost to the solidus, the line representing melting poist is depth. and is comsistent nith $J$ softening in the velocity depth praffic for monnguske waves observed in tecent selsinumetet ditia.

This conlintration of a higli-temperolure interion for the Moon has also revived inletest in the maston

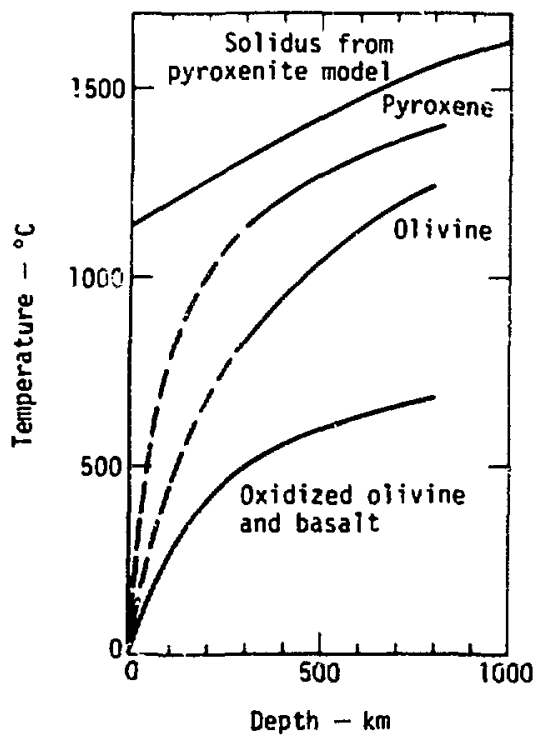

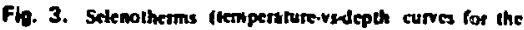
Mow). The otivine ano pyroxanc curves are cakulated from out iboratory conductivity meawrementi ard NASA condectivity-n-depth proflich. The previous cthine and bacil sefenothem was based on faulty electrical conductivity measurentents. The prroxene curve comex withis about $100^{\circ} \mathrm{C}$ of the solidis, tot ration of meloine polat with depth. Uncextainties ia the dnta intepretation amount to aboul $=151-200^{\circ} \mathrm{C}$

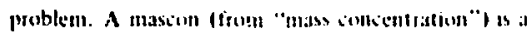
gravitational antumaly atl? of several reghens on the Moun where gavoty is measureably hught than on the rest of the arfuce. Our nouger dita win the subjest

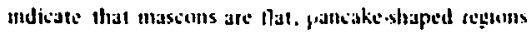
with densitses highter than their surroundnags. lyatg somewhere bolow the sarfate of several af the basalt-filled mana. Masiont sameters alce up 10 laundreds af kilometres

From their shape and then location heneath tharia. it appears that ated mascion maly be the tesult of an impactug metcor fonnum a sater that subsequent, litled wilh lave lo lond the relatwely smooth,

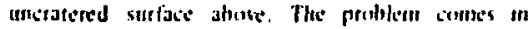

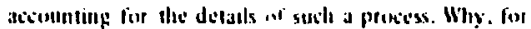
instante. did the mascions : lijy pust below the subface"

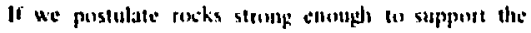
extra weight of the allasint. llus unples tentretaleses far below the solidat. Vifhers. then, did the lava

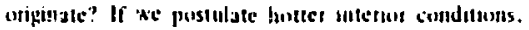
raprable of supplying lova, wate prevented the moscon from coalescing intu a ball and sukung down tu the Eenter af the Mtom?

The new temper-'tuse dato funtsl a definite base mint on which an less forme hypulheses of mascous ongin. Combined with information on the Moon's couling rats. it could help to date the events that fonned the maseoris by plating an uppes lume on theif apes.

The imptoved electritial sondactivity inforstotion and thit lechaiques we developed for measuring conductivities under extreme conditusns lave several spplications here sm lisrth. The electrical conductivities of weaprials materials ate important in studying the belavior of these niaterials undet extreme conditions. Ons measurentents and me hlonds lave mode significant contributions in this ticld.

In entrgy resourse developmest, une of the problenis in controlling at sim coal gasifisation is Io Jefine the sliope and posstion of the butin fount as it presceeds underground. Out stidies of the temperature-induced changes in conal's elcetricul conductivity suggest that electromagnetic ptobing may prove a feasible way to trace the bum front. Sinilarly. oul data on the condwativitics of basolt and such minerals as aibitc are being used in ERDN's program to niap "dry, hot-rack" geothermal resuurces.

Finolly, sone of the sanie considerations that apply to the Moon can be applied to the Earth as well. Figure 4 shows where the geotherm (Iemperature-vs. depth curve for the Earth) calculated from ous 
Fig. 4. The variasun of timperature with depth in the liath, calculased from ini dat on thine skctical conductivity and on condertivity-us-depth dats from a varact) of sources. The wolidus is shown for comparixon. Inkerstitial water interferes with the measurements dowil to absul $220 \mathrm{~km}$ : only heike that depth is the sonductivity a reliable :adication of iemperature.

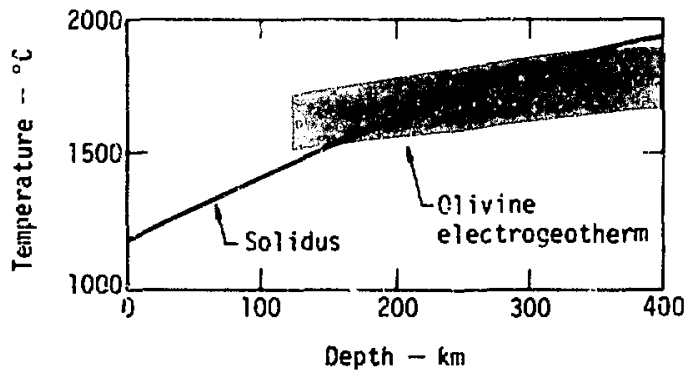

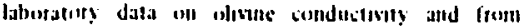

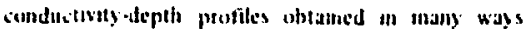

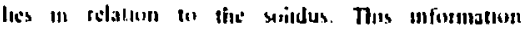

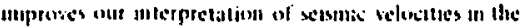
fath by tefitumg cour estumates of the states of the

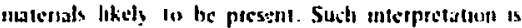

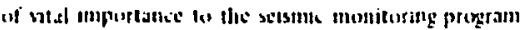

by holpung us lo verify compliarwe ivith treatics finuting the size of nuclest lests.

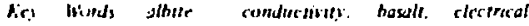

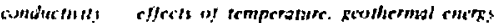

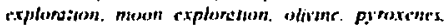

\section{RECOGNIZING THE PATTEAN OF CALME}

Under EROA's Aechnology utilization program, LLL is helping the San Dikgo Police Depasment explure the userulness of atuonoted crime onalysis. Using an UL computer code. we have denonstrated experimentally that computer pattem recognition is a feasible methud for analy ring crime. It now remsins for us to complete the technology transfer cycte by xsisting in the transition from the experiniental system to an operational one. Then, the San Uiego police can use it as a time-saving. cust-effective toul for allicating the department's avalable manpower naose effectively to solvc and prevent crime.

Police depastments loday ate fecling! tis conomic pinch of having to fighi increasing cribt: with limited nonjower. As a result. they are looking for ways to automate tinteconsuming adninistrative funtions acrforned by theis affitsers.

The Federal Low Enforcement Assistante Alniuistration, in recogsizing this prohlem, last year gave live San Diego Police Department a gram to construct an Automates Regional Justice informution System for use throughout San Diego County. One of

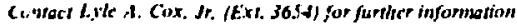
ont this sriticte. the goals of this system is the implementation of an automsted crime anz!ysis tapability.

"Crime anjlysis" is non a precisely defined or well understuod term. but is genetilly interpeted to be the extraction of useful information from the study of insturical irme data. Crinte analysis tecteniques used today range from simple "brainsturming sessions" between senior polsce personnel lo extensive stutistical analyses of srine reports. To date. no rechniyue has parced completely satisfactory, although oecasional suctesses liave been encouraging.

Because of the data-unalysis problenis of several LILL. tescarch projests. a computer pattem recogaition capability las been devcloped at the Labotatory. The polential demonstrated by pattern recognition techniques in various physical and social sciences suggested that substiantial advantages might be realized througl applying these methods to crime analysir (see box on p. 6). LIL was requested to panticipate in a technology transfer effort on crimt analy sis with the City of San Dizzo.

Up to that time, litte of no pattern recegnition analysis had been done with real crime dats. Our participation was thus to evaluate the capabilities of pattern recognition methods to perform crime analysis. 
A brief study of the nature of the problem was performed. and the planned project was broken down into the following basic phasas: feasibility. operutional potential survey, exicnded variable selection, and aigorithm choice.

\section{Feasibibity}

The first phase - finding out if pattern recognition would work in erime analysi; - was cxpe:imental. Our goal was ic determine if sons relotionships existed that would allow us to predict the likelihood of a crime being solved based on cer:ain variables: njture of trime, location. tinte, elc.'

Our fitst task was to review tne crink stutistics provided by the San Diego Police Department. They covered the first quarter of 1975 and were in the iorm of a wasgnetic tape contuining 21056 lines of datu. bach line represented one crinte repiont and its related variables, or infomiation fields. Aîter rejecting lines with errors or uncertainties. 14 were left with $1 / 645$ case records. From these records we were able to summanes stutistically the different trintes totaling 26 and ranging froun petty thert to himmide.

This review gave us a belter understanding of the dats we would have to deal with ill starthing for relationships which would allow us to predict that particular crime could be solved. Informo.tion tields from the San Diego Police Departsuent tope and thear refomitted strusture fist PATTER use (see box on p. 9) are given in Table 1 . Note that. in refumatting. we assigned one of three properties to eud tast closeal, open, or material recosvered. For cour purpuses. we considered the San Diego Poliec term "clesed" to rikean solved.

Aelditionilly, the data were displayed graphically in a munher of ways to facilitate visual interpretation. (me display used digitized erime locations to presdace a the -limensional plot of stimat frepuency inganst an cutline of the tity itself (Fig. 5).

- dially, we used PATJt:k to find out how oflicient various techniques were in prediting susceptibility (o) solution of newly eported irimes. We based this

\section{COMPUTER PATTERN RECOGNITION}

Computer pattern recopsition combines computer science with the problem-solving techthicques of applied mathematica. Over twonty ysurs ago. as the first digital soniputers becinte avilable. researchers reslized that their usefulness was not confined to nutnerical salculations but that computers could play a much broader information-processing rule. Some of the first programs in this atea weic designed io atutomat: decision-making processes. such as recognizing printed alpha-numeri; charatters. Froin these warly afforts. the fiele of puttem recognition has evolved.

Some pattems may be physically representable, such as printed letters on a page or the measured echoes of sonar and radar units. Other patterrs may be only abstractions, such as patterns discerned frotst psychulogical or social data. Regardless of their type, it is by recoginzing patlerns that we interpret the world abotit us. Conside: huw a young child learns to differentiate between mother and father. ite learns to interpret the pa!terns of his senses and to make dyisions based tpon his interpretations. Clearly the child's learning process reguires two steps: (1) observisig patterns and determming a decision rule and (2) appiying this Iulc.

Fimilarly, computers can be progrummed to recognize patterns by lirst it." crimes) of known properties (e.g., solved or unsolved) as a training sti. A similar set of data wnose propertics ate unknown are then analyzed 'o sec if they fit the patteni of the training set. This allows the scientist to find o: predict a property of the variables that cannot oc measured di ectily but is thauglat to be related to the variable by some uriknown connection.

Recently, anid discussions of the "information explosion," the need for auturiated information systems becamm clear. The emergence of such systems accentuated another problem - that of making intelligent decisions based on the vast quantities of data available through these systems. Using computerized pattesn recognition techniques, we are able to consider large amounts of dals ist relatively shirt geriods of time and to extract and apply the desired information efficiently.

Pattem rccognition tuctiniques :oday are used for solving data-prosessing problems in an increasing number of diverse preas: aptical character rrcognition, speech recognition, spectrographic analysis, system design, weather prediction, medizal diagnoris, and many others. These cempurerized techniques give today's sciertist a means of handling the tecious task of seducing large amounts of data. 
Table 1. Crime information

lields recsived from

the San Diego Police

Department and their

restructurol format

for computer use at

LLL: phase 1

Information felds

Compuler varibbles

\begin{tabular}{|c|c|}
\hline $\begin{array}{l}\text { Crime type (San Diego Pollce } \\
\text { Dept. coule) }\end{array}$ & $\begin{array}{l}\text { ․ Hour of day } \\
\text { 2. Digithed year/day }\end{array}$ \\
\hline $\begin{array}{l}\text { Cenws uract number for } \\
\text { the ares of ccrutrence } \\
\text { (geographical lexation) }\end{array}$ & $\begin{array}{l}\text { 3. East/west coordinates } \\
\text { 4. North/south courdinales }\end{array}$ \\
\hline $\begin{array}{l}\text { Year of exsurrence } \\
\text { Julian data }\end{array}$ & $\begin{array}{l}\text { 5. Predicted froperty } \\
\text { (characteristic): } \\
\text { l=ease closed }\end{array}$ \\
\hline $\begin{array}{l}\text { SDPD case number } \\
\text { Applicsis: pend coule } \\
\text { certion }\end{array}$ & $\begin{array}{l}\text { 0.5=property } \\
\text { (materid) or } \\
\text { (covered }\end{array}$ \\
\hline $\begin{array}{l}\text { Strect address where crime } \\
\text { acculed }\end{array}$ & F=case upen \\
\hline \multicolumn{2}{|l|}{ Hour of day } \\
\hline $\begin{array}{l}\text { Status indicator, giving } \\
\text { stans of case }\end{array}$ & \\
\hline
\end{tabular}

prediction on inferences from a historical training set. which contained a representative sample of erimes whose solution status we knew. Out preliminary results indicated that there was insufficient information to support accurate predictions.

We used four tasic variables in these first experiments: time of day. time of year. east/uest coordinates $(X)$. and north/south coordinates $(Y)$. But our accuracy in predicting whether a crime wis solvable was essentially the same as that represented by the statistics in the training set (equivalent to a randori, guess). We had hoped for a higher value.

After reexamining the original crime data, we found a number of useful relationships that, in terns of added variables, nught give us a higher predicrive accuracy. For example. we realized that although we had included the north/south and cast/west coordinates from a tract map of San Diego, they were not truly independent. San Diego has an irregular boundary and its population is not distributed uniformly. We had no linear measure of intemoint distances between crime locations. Consiquent'y, as a simple mathematical technique to introduce the inhere.tt nonlinearity, we added a fifth variable whicit was propurtional to the crossproduct of the $X$ and $Y$ coordinates.
Also, we prepared a new data set, containing 100 crime cases - 20 each of rape, robbery, assault, burglary, and grand theft. Two other variables were then added: percentage securrence ind percentage of closed cases for each of the five cimes.

Our resulte from analyzing the 100 crimes using 7 variables are given in Table 2 . Note that the nulticlass technique achieved a $15 \%$ better predictive accuracy than one would expect from pure random guesswork. This increased accuracy had a twofold significance. First, it inditated that we werc able to predict the probability of solving a crime with belter accuracy than that suggested by the crime statistus. This carried with it the inplicution that with this predictive techutique, the San Diego Police Department could optimise it. naanpower resources by assigning officers to crime cases that had a better chance of being solved.

Thic othe: significance of the $15 \%$ increase in accuracy was that it resulted from the three added variables. If we could isolate and measure additional variables. we might further increase our predictive acturacy.

Although these results were promising, our work was essentially an experimen! designed from the point of vicw of scientists involved in an arbitrary dat3-analysis problen. However, we felt we had accumplished what we had set out to do: show that pattern recognition was feasible for autornated crime analysis. Also, we had gained a better understanding of the property and valiable relationships. Based on this progress, we went on to the next phase.

\section{Potential}

The goal of our second-phase research was to select an operationally reasonabie model and to optumize the patten recognition performance of the currently available variables within the context of the model. This meant that we would have to optimize the model's variables to yield that information best suited to tıe San Diego Police Department in allocating nanpower.

Our work in phase $I$ indicated that we might increase PATTER's predictive capability ty isolating and measuring factors in the crime data whose relationship to a basic variable was not apparent. We discussed these factors with the San Diego Police Department and then reviewed the original 21056 data records. This time we formatted 10 variables:

1. East/west coordinates $(\mathrm{X})$.

2. North/south coordinates (Y).

3. XY (crossproduct). 
4. Hour of day when crime occurred.

5. Date of crime (day of week).

6. Time certainty (indicating whether a crime was committed in daylight, at night, or if the time was uncertain).

7. Type of crime (indicating whether a crime was against a persen or against property).

8. Closure rate (A), a crime's probability of being closed, as indicated in the original sample.

9. Occurrence rate (B), a crime's relative rate of occurrence, as indicated in the original sample.

10. AB (product of variables 8 and 9).
In the data set for this second phase, we again excluded entries vith obvious data errors and entries that were "unsolvable" (e.g, natural deaths and suicides), but we retained entries with known uncertainties. This left us with 19935 cases comprising 24 different crimes, as onposed to 26 in the first phase.

Instead of the 100 crimes selected for the training set in the first phase, this time we randomly picked 500 that had occurred before a given date. Based on this training set, we then developed classification rules.

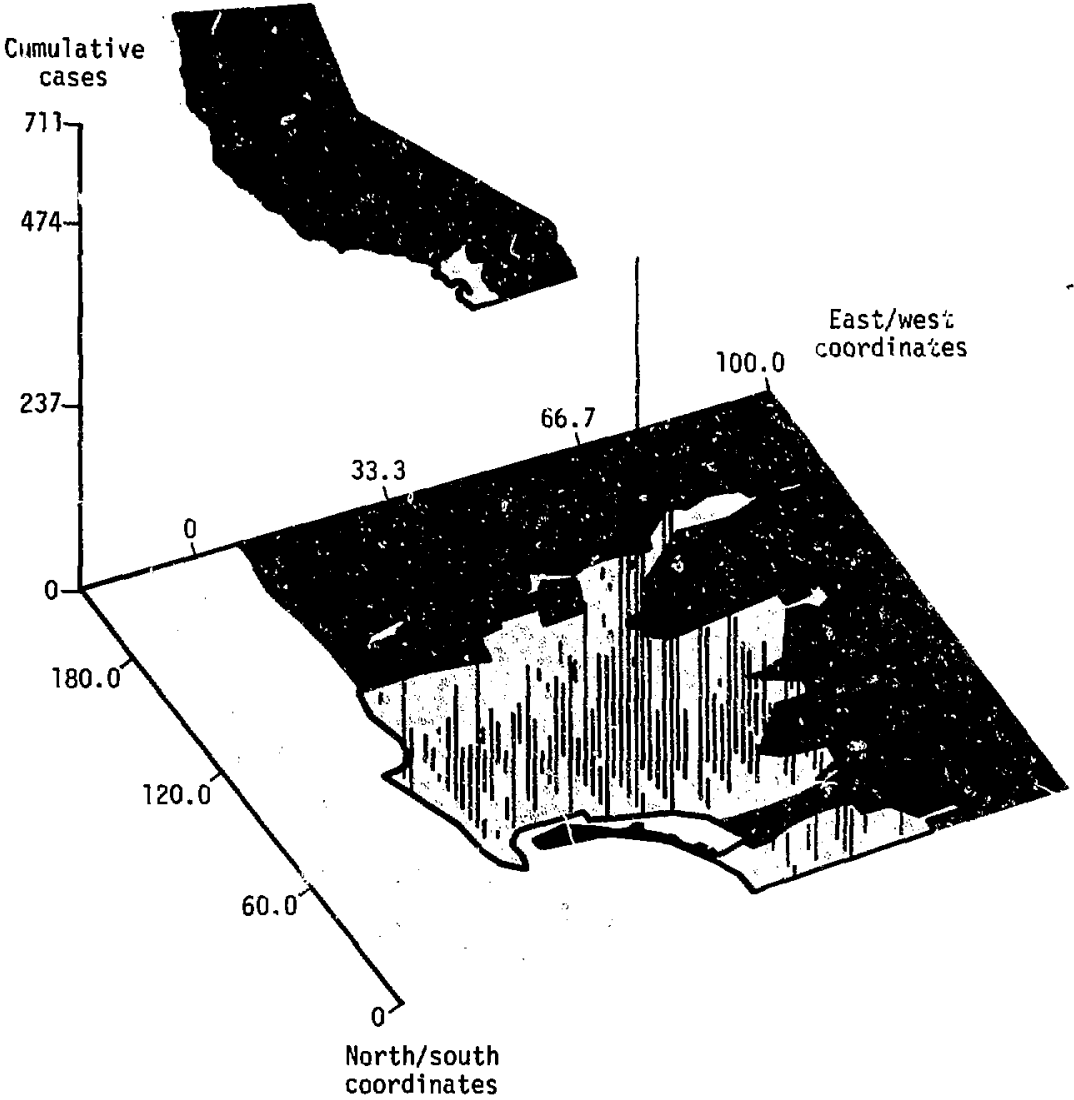

Fig. 5. Computer dikplay of crime datz: digitized crime locations platted in three dimensions on a map outline of San Diego, 
Tablo 2. Phase 1 rewults of pattern recognition analysis (PATTER), with 7 variables for 100 crime cases (20 exch of rape, rohbary, assault, burglary, and grand theft: 10 cases open, 10 ctosed) - -

PATTER accurzy

Variables

(in predicting a crime is solvable)

l. Hour of day

2. Time of year

3. East/west coordinates (X)

4. North/south coordinates (Y)

5. $\mathrm{XY}$ (crosproduct)

6. Percent closed originally of each type of crime

7. Percent of each type of crime in original sample
K-nearest-neighbor technique:

$\begin{array}{cllll}K & 1 & 3 & 5 & \vec{r} \\ \% \text { comect } & 63 & 58 & 57 & 56\end{array}$

Multiclass teclınique: $65 \%$ correct

\section{PATTER AND ITS TECHNIQUES}

PATTLR $^{2}$ was developed at LLL to solve scieritifis problems with pattern recognitiun techniques. Written in FORTRAN IV, this computer code can be used in an interactive mode, especially where fast graphic devices like CRT displays are available. It is specifically suited for modeling analytic processes, for use in spectral analyses, and for solving complex problens ir, data analysis in which the physical properties of large amounts of data are not well understood.

For a given collection of data, the system will try to determine if prediction of an unmeasured property of the data is possible based upon the information at hand. In constructing the systeni, we have striven to preserve and foster the capability for PATTER to answer ant only "YES" but "NO" whenever such a response is warranted. When properly employed, PATTER will act upon a data set in such a way that it becomes apparent if useful information beyond that already discemed is contained in the data.

The input data consist of a number of patterns (NP), or abjects, for which a number of variables (NV) have been recorded. This data tabulation constitutes a "pattern space" whose structure is a matrix of NV rows and NP columns, accommodating the application of linear algeora. Mathematically, each puttern can be thought of as a single point in NV space.

A well known technique that can be used for predicting an obscure or unknown property of an object is to apply the "K-nearest neighbor" rule. This rule classifies unknowns on the basis of the common properties of their K-nearest neighbors. If we accept that each pattern is a point in NV space, we can reasunably assume that in some cases points close together will be more similar than those more witely spaced. With proper data presentation, we can expect to see clusters or groups of points in which all members of a cluster exhibit some similarity or common property.

If we accept that closeness is related to similarity, then most of a point's neighbors can be expected to possess characteristics the same as those of the point in question. The K-nearest-neighbor technique is based on this concept. To predict the characteristics of a given (unknown) point, we poll one, three, five, or seven of its nearest neighboring points. The unknown point's membership in a cluster is determined by majority vote. Since each cluster is associated with a characteristic, the process of deciding cluster membership in effect predicts the point's characteristics, e.g., whether a crime can be solved.

Another useful technique is the nulticlass linear classifier. ${ }^{3}$ This rule also relies on the clustering properties of the input data. But rather than deciding a point's membership according to majority rule, it draws lines or planes in the patterm space, effectively isolating each cluster. We then use these artificial boundaries for predicting the properties of unknown points. Given an unknown point, we need oniy see within which boundaries it lies. Because the boundaries confine one cluster to one region, we can assign the unknown point to the cluster whose region it shares. This assignment allows us to predict that the point's properties are similar to those of the cluster's other mentbers.

In contrast to these two discrete techniques, a number of linear and nonlinear continuous techniques exist, ranging in complexity from a conventional least-squares fit to other more sophisticated techniques. We have incorporated some of these options in the code, too.

Since pattern recognition techniques are sensitive to data representation, PATTER includes nt frous statistical and mathematical routines for transforming the processed data into their most usable form. These range from autoscaling, which nonmalizes the pattem space, to sophisticated routines that make points more easily discemible and enbance their classification. ${ }^{4}$ 
To judge the accuracy of out predictive rules, we prepared a test-data set. Our data consisted of 200 crimes, also picked at random, that had occurred at later dates than those in the training set. We felt that this would guarantee a true test of PATTER's capabilities to predict which crimes were the most solvable. Two hundred cases spanning the entirc range of criminal activity represent a valid example of a single day's case load for the San Diego Police Department. Every day, supervisory personnel are faced with similar case loads and must decide how best to allocate their limited manpower resources to resolve these crimes. If pattent recognition techniques could establish a priority list for case assignments, police supervisors would be freed from a large part of their routine administrative burden.

A subroutine of PATTER ranked the test cases from i to 200 in order of probability of solution. The $50 \%$ point occurred between numbers 76 and 77 on the list. In looking at the records for the 200 cases, we found that 34 had been solved. Of these cases, PATTEL had listed 20 in the first 76 of the listing. The relative cost effectiveness of solving 20 out of 76 cases (26\% success rate) by automated crime analysis, as compared with solving 34 out of 200 cases (17\% success rate) by cirrent nonautomated methods, is encouraging but may not show the full leverage available if manpower is concentrated where it can do the most good - those cases which are most susceptible to solution. We have not considered the police department's method of assigning investigators to cases, and this could affect whether or not a crime will be resolved.

In the absence of specific data on case assignments, we were unable to compare results that would yield accurate costeffective values. The availability of such data in the future will make such comparisons meaningful and let us judge how effective PATTER can be in an operational environment.

\section{Extended Variables}

Our use of PATTER in phase 1 indicated that, with
3 limited number of variables, pattem recognition techniques can help analyze crime statistics with predictive results that are $65 \%$ accurate. Phase 2 revealed that PATTER's predictive accuracy can be increased by incluting additional variables, and that this predictive capability appear to be useful in police operations.

Both phases underscored the significance of choosing appropriate variables when applying pattern recognition to crime analysis. We need still more information. As part of phase 3, we will tap daca that the San Diego police routinely collect but that they never store in the department's automated data-processing system: information relating to suspects, witnesses, modus operandi, nature of property involved, etc., in crinies. Then we can analyze the role of these variables in the pattem recognition process, and determine if the Autumated Regional Justice Information System should include these additional data fields in its computerized retrieval system.

\section{Advanced Algorithms}

If it is to yield the best results, any automated data-processing system must operate according to a well defined set of rules in a finite number of steps. In the final part of our study, we will select the more efficient processing algorithms that make use of the variables selected in the previous phase. These algorithms can then be incorporated into the San Diego system. Our last responsibitity will be to close the technology transfer loop. to assist the San Diego Police Department in imple:.enting the appropriate pattern recognition techniques, thereby providing San Diego County with automated crime analysis.

Key Words: automated crime analysis: patsern recognition: computer simulation technology. 


\title{
ENVIRONMENT. HEALTH AND SAFETY
}

\author{
GETTING THE fACtS ABOUT OZONE
}

The new Satelite Ozone Analysis Center at LLL soon will be assimilating the flood of data provided by a new series of Air Force satellites for facts about ozone. Among other things, we will be producing daily high-resolution global maps of ozone concentration. Correlated with ground observations, these maps will help us to establish the current averuge ozone level, to check how solar flares, volcaris eruptions, and atmospheriz nuclear tests change that level, to detect long-term irends in ozone concentration, and eventually to predict the effects of various forms of atmospheric pollution.

Contact James E. Lovill (Ext, 8811; for further information on this arricle.
The advent of aircaft capable of ilying in the stratosphere - e.g., the Concorcle, the USSR-SST, and the 747 SP - raises the serious question of how their exhausts will affect the ozone layer. There ate also other ways by which the ozonosplere may be significantly altered, from both man-made and natural sources. Fluorocarbon releases, for example, may someday amount to enough to affect the ozonosphere. and atmospheric nuclear explosions release large quantities of $\mathrm{NO}_{x}$, which also destroys ozone. The long-term influences of all these effects ase unknown, and this lack of knowledge is in itself a cause for concern.

Land based ohservations indicate that there has been a world-wide increase of ozone during the past decade.

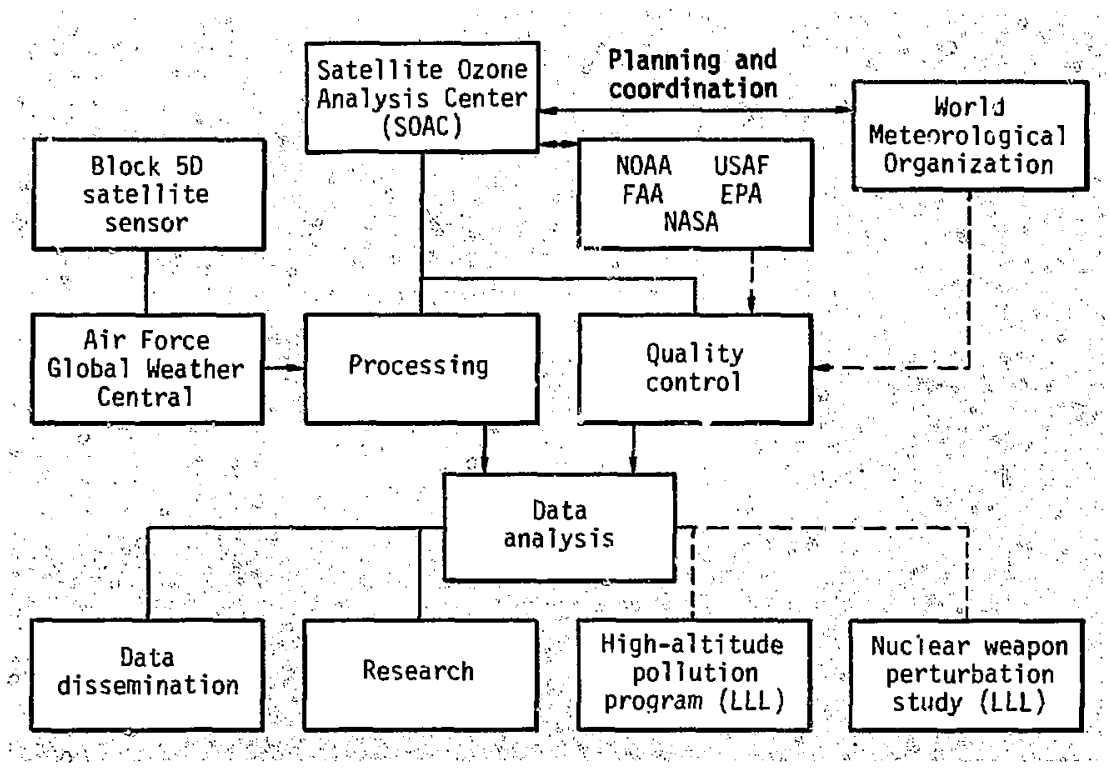

Fig. 6. Operational diagran for the Satellite Ozone Analysis Center. Coordinating with national and international agencies, the Center will accept data from the Block-5D satellite sensor through the Air Force Global Weather Central, process and compare them with indeptndent data (quality control), and analyze and disseminate the data both for outside agencies and for our own research. 
Studies of the availablic satellite data suggest that these observations inay have been biased by a poor disinbution of the stations. We will need much more satellite data to resolve this issue.

Table 3. Spectral centers, widths, and noinequivedent spectral rediences (NESi!) of the ozons, compirrature. and water-vapor channals of the Block-5D, cros. track-scenning multifilter rediometor

\begin{tabular}{|c|c|c|c|c|}
\hline \multicolumn{2}{|c|}{ Center. } & $\begin{array}{l}\text { Width. } \\
\mathrm{cm}^{-1}\end{array}$ & Spicies & 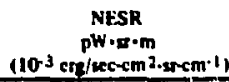 \\
\hline 9.8 & 1022 & 12.5 & $\mathbf{o}_{3}$ & so \\
\hline 120 & 835 & $\mathbf{s}$ & Window & 110 \\
\hline 13.4 & 747 & 10 & $\mathrm{CO}_{2}$ & 120 \\
\hline 13.8 & 725 & 10 & $\mathrm{CO}_{2}^{2}$ & 110 \\
\hline 14.1 & 708 & 10 & $\mathrm{CO}_{2}^{2}$ & 110 \\
\hline 14.4 & 695 & 10 & $\mathrm{CO}_{2}^{2}$ & 100 \\
\hline 14.8 & 076 & 10 & $\mathrm{CO}_{2}^{2}$ & 90 \\
\hline IS.0 & 668.5 & 3.5 & $\mathrm{CO}_{2}^{\circ}$ & 300 \\
\hline 18.7 & 535 & 16 & $\mathrm{H}_{2} \mathrm{O}$ & 150 \\
\hline 24.5 & 408.5 & 12 & $\mathrm{H}_{2} \mathrm{O}$ & 140 \\
\hline 22.7 & 41.5 & 18 & $H_{2}^{\prime} \mathrm{O}$ & 90 \\
\hline 23.9 & 420 & 20 & $\mathrm{H}_{2} \mathrm{O}$ & 120 \\
\hline 26.7 & 374 & 12 & $\mathrm{H}_{2} \mathrm{O}$ & 180 \\
\hline 25.2 & 397.5 & 10 & $\mathrm{H}_{2} \mathrm{O}$ & 160 \\
\hline 28.2 & 355 & IS & $\mathrm{H}_{2} \mathrm{O}$ & 250 \\
\hline 28.3 & 353.5 & 11 & $\mathrm{H}_{2}^{2} \mathrm{O}$ & 330 \\
\hline
\end{tabular}

LLL's new Sutellite Onone Analysis Center wans established to provide atmospheric whone dala to the national and internattonal stientific conumunitics and to perforin research directed toward a more complate understanding of the variability of the ozonosphese. We will be analyzing ozonc data from a new series of satellites and measuring the Earth's ozone variability. We will also be providing Jaily maps of clobal ozone distribution for inpal to computer modsls of the atmosphere. Figure 6 outlines how these various lasks will be organized.

The sensor used in the progran will be aboard a U.S. Ait Force satellite, thic Block 5D, in an 835 -km cir:ular polar orbit. Four Block-5D satellites have been suilt. each with an stintated lifetinte of at least two years. Dala will be received from the first of them carly in $19 \% 7$.

The Block SD conluins a new scanuing sensor: a crosstrack-scanning. multiflicer radiometer. The sensir reads and reponts 16 spectral radiance values. These include one at $9.8 \mathrm{mu}$ for mejsuring ozune absoption. one at $12 \mathrm{\mu m}$ for determining surface radjance, jix in the 15. It 15 - $111 \mathrm{CO}_{2}$ band for delineating how temperature varies with altitude, and cight betveen is and $28 \mathrm{~mm}$ fot measuring vertical and total wajer-vapor distribution.

Table 3 lists the spectral cemters, width5, and lloise equivalents of all these radianic cliannels. Note that the noise-equivalent spectral radianco (NLSR) for the

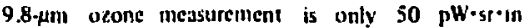

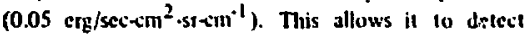
very small thanges in orone.

The Blewk-5D satellites are controlled trom sises in Maine and Washington. As a satellite passes overhera.

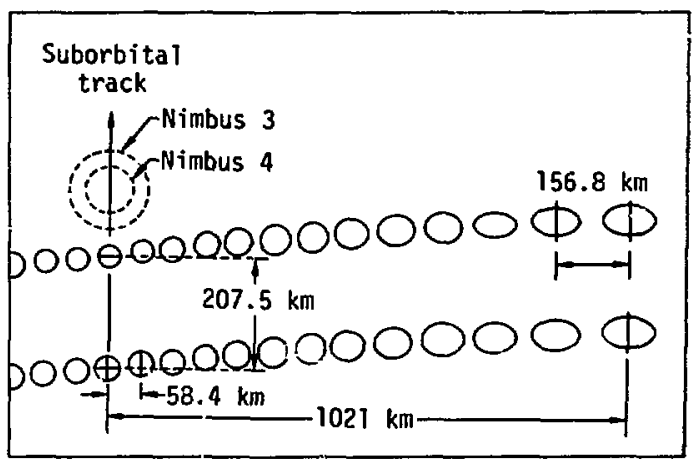

Fin. 7. Calculated tiath profection of the ithe hall of the Dloch-SD tenor's wess beometty. The scan exiends symmetrically out of the ptente to the keft. Fach pot in succesion is riewed by 2116 of the sensof's channels. The field of view ba minimum directy under the wellike and spreads out into an ellipe of elther side. The minimum field of ricw is only $39.3 \mathrm{~km}$ diam. Dotted circke indirate he minimum fields of riew of the IRIS xwiors on Nimbus 3 and 4 . In a day the Bkrek-5D satelite will san aboul $68 \$ 00$ fedds of view, 30 timen as many as any provibus ateditite. 


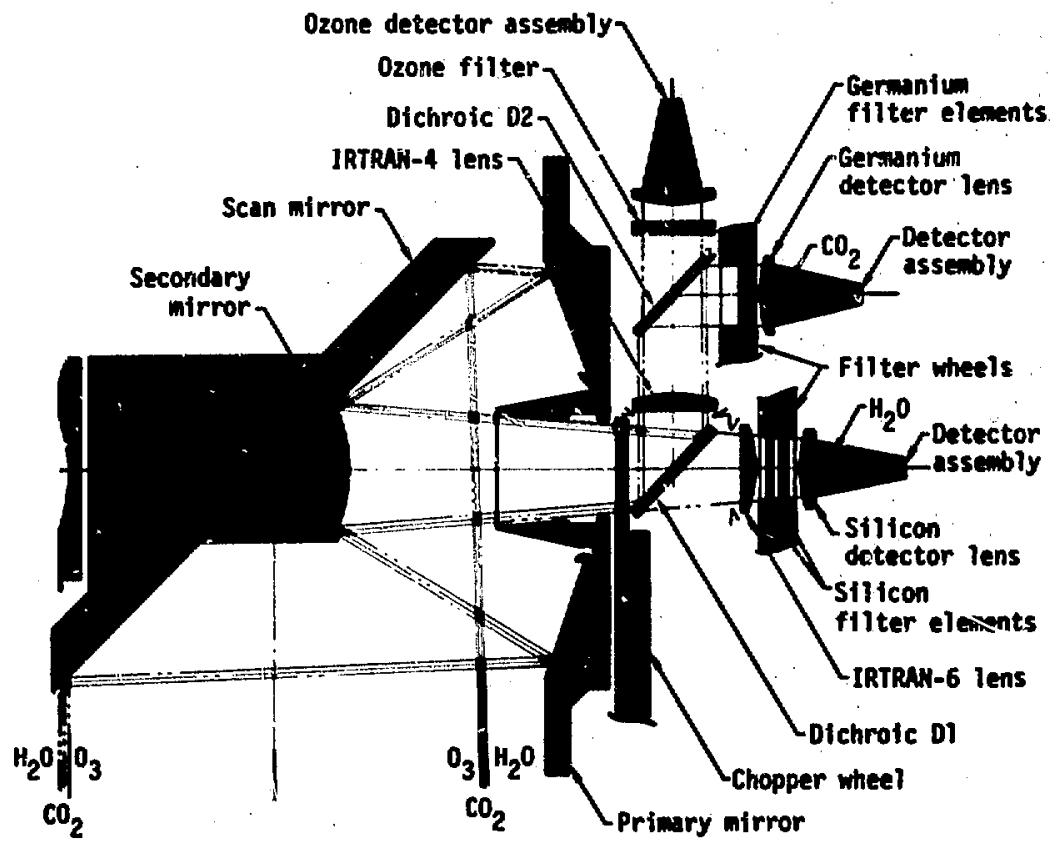

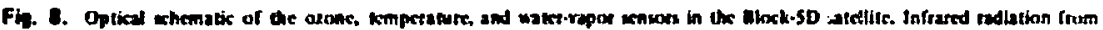

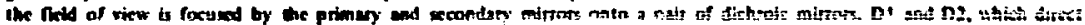

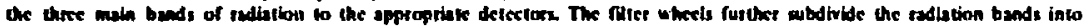

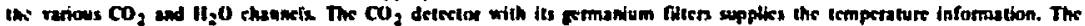

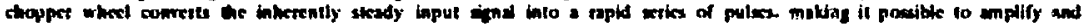
mresure the siont.

a tape recorder un bond transmits the slured data back to the contral sistion. $A$ coumnunications satellite ltien relays these data to the Air Force Global Weatier Central in Nebrask.

The Weather Central transforms the sateltite's 16.channel, digitized, calibrated, and liarth.located data into a more conrenient fombt: 27 8-wotd (36-bil) packet for each sensor sample point. There are 2S sample points per crosstrack scan, 190 crnssirack scans per orbit. and 14.4 orbits per day. This yields one osone. six teniperature, and elpht water-vapor mesurements for cach of 68400 loxations on liath each day.
Figure 7 shums the sensur's sian geometry. At the sububital point, the field of view iesulsed is $39.3 \mathrm{~km}$. This is an inprovement ove the fields of view for carlier satellites: 94 and $150 \mathrm{~km}$ for the IRIS sensours un Nimbus 4 and Nimbus 3. The instrumint data-seturn bate is alos 30 liuks faster than that of any peviuus oxane sensot, acemplisting in a day what fommerly touk a momth or nute. This greater infomationefalicring tale can produce rapid-fite inazes to capturc shoti-ferm chantes. It may also be allowed to accumulate to form limesxposure inuges Uhat bring out in greater detail the slructures of the nore permianent fealures of the ozonosphicre. 
Figur: 8 indicates the placenkent of the radiunxeter's optical components. The primary and secondary nirrors focus the incoming infrared radiation onto a pait of dichroic mirrors. D1 and D2. These mifrors. by selective refloition and imingission. divide tic infrased adiation into three main wavelength bands and direct exith band into a different detcilor.

The $\mathrm{CO}_{2}$ and $\mathrm{H}_{2} \mathrm{O}$ detcetors have filter whec's tha' further subdivite these radiation bands into seven and eight nartow channcls. respectively. Neither of these detectors can look a: :nore than :ne chanatel at a tiske.

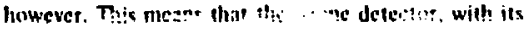
single channel, is gathering energy continuously, white the whet deteclors ate switching from diannel to diannel.

Between the secondary inirfor and the first dichroic numor there is a chopper wheel with evenly spaced teelh that breaks the beam into a rapid series of pulses. This converts the slowly varying inconting light into rapidkir nuctuating detector signais that are easy to

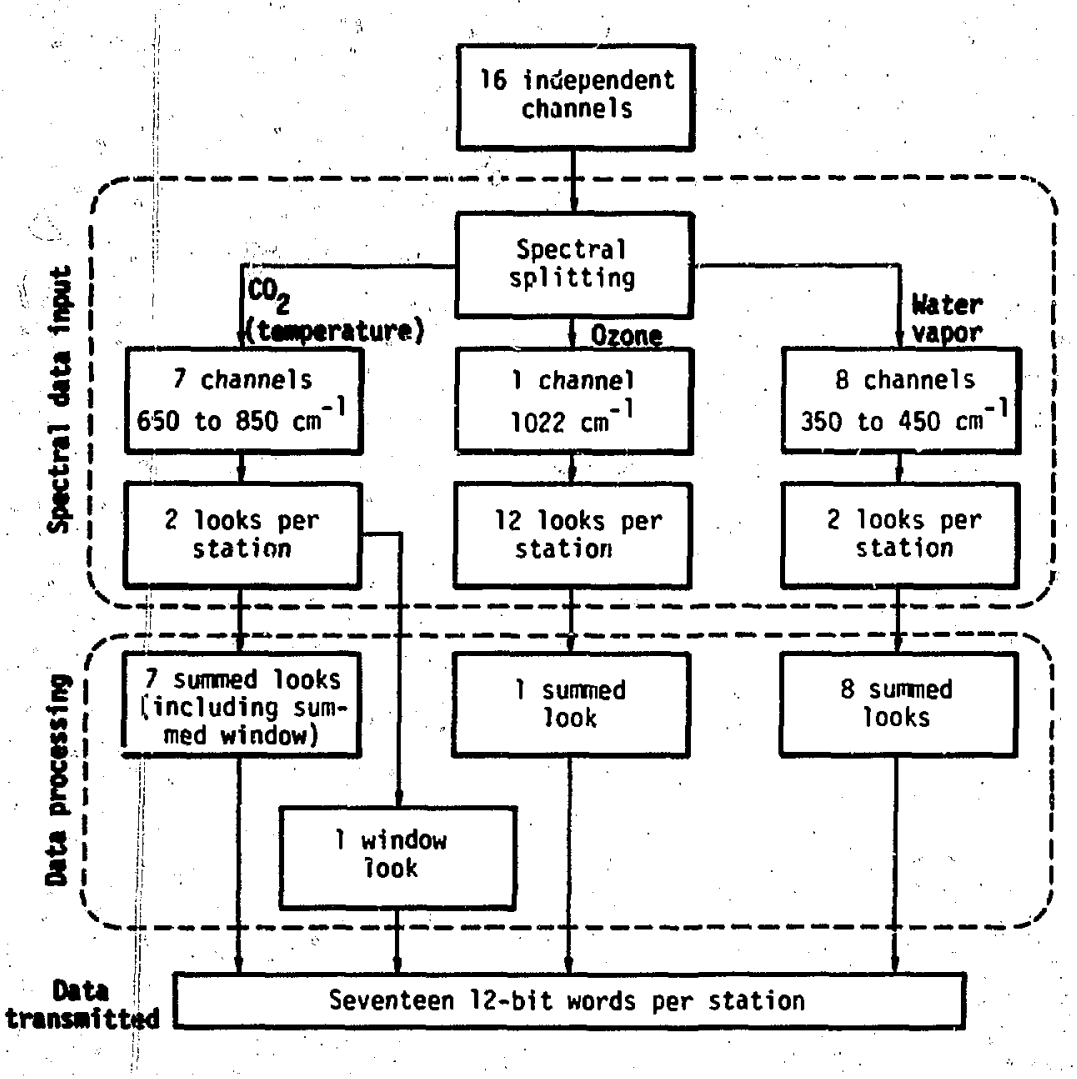

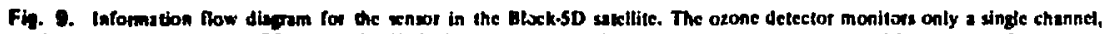

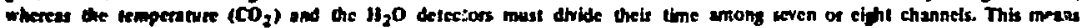

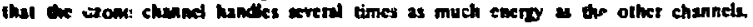


Fig. 10. Totatazone varbion during one otbital pass from weslem Siberia, acrow the weskern Pacitic and Auntralia. to Antaretica. The duta from which this curve was constructed wert gathered by the Nimbut-3 atetlife. Thete is ange of narly ofactor of 2 in azome concentration between the polar and the equatorial myons.

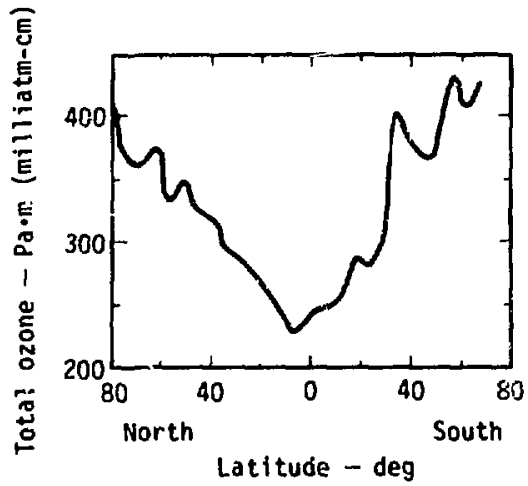

Fig. 11. Totatoxone distribution ove the nordhern nemisphete wersend over a 93-day period, April to July. 1969. The contours indicale axonc concentration in Pacel metres (milliatmosphese-cent(metre). This map, drawn from Nimbus 3 data, is an example of the tind of map that we intend to produce deily. The sey ares. outlined by the $240 \mathrm{pm} \cdot \mathrm{m}$ contour. indicates a semipermanent IGjon of low ozune concentration located west of the Ptillipine Islands and noth of Austrille. This phenomenon is nol curtently understood: we hope chat edditiond dats from the Satellite Oxone Andyd Centet will help to explain il.

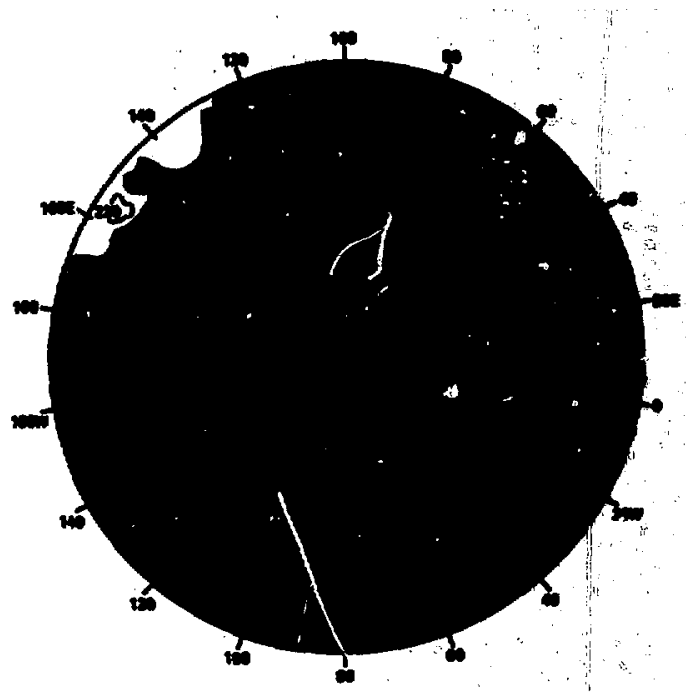

amplify and digitize. Each of the light pulses is temred a "look."

Figure 9 outlines the dats flow in the sensor logic. The output from the data processing section is stured in an onboard tape recorder for transnission whenever the satelite comes within range of one of the ground control stations. The 1712 bit words transmitted for cach "station," i.c.. sample location, contain the entire readoul from the 16 clunnels of information.

Onte we receive this infomation, we must first convert the radiance values into measurements of ozone concentration, teniperature, and wate'syopor distribution. This is a matter of mithematical inversion, using radiative transfer equations and 
spectruscopic imanission functions to deduce the vertical temperature and compositional profiles. We lave developed inversis $x$ techitiques that provide solutions to the maliative transfer equations, and we have compiled transmission funcliuns by combining srolecular theory with field and laboratory measurements.

We will be conparing the satellitederived totai-ozone values with medsurentents from selected totalozone grourd stations at various locations in earh hemisphere. For example, our total-ozone value will be conifared with the Dobson Spectrophotometer value whenever a softwate progrant computes that the stellite ozone value comes from a spel within $50 \mathrm{~kJ}$, of a grnund station. In addition, weekly and monthly Dibson average values at stations in the ground network will be compared with the satellite-derived average values.

As a further check, we will be comparing the Block-SD uzone values with those obtained from the NASA TONS ozone sensor, which is scheduled for a 1978 launch date. When the second of the four Block-5D satellites is launched later in 1977, we will be cornparing the ozone channels of the two suiellites with one anozter and with the totatozone ground nelwork. (After the second SD systetn is lausched. two satellites will be mantained in orbit into the 1980's.)

An additional feature of these comparisons is that the polar orbils of the iwi) Block.SD salellites will permit simultaneous observation of widely separated ozone responses to transierit events. like volcanic eruptions and solar Mares. They will also yichd data on day-to-night ozone changes for particular locations all over the world.

Figure 10 shows the total-azone measur ment along a single north-south pass of the Nimbus-3 satellite. This particular pass started in western Siberia, crossed the western Paific Ocean and Australia, and ended in Antarctica. The total ozone atmospheric calomn varies by almost a factor of a between the polat tegions and the equatur.

We will be parforming a computer spline anslysis on the 68400 daily ozouic neasurements from the Block-5D salellite and displaying the data in a glabal $1^{\circ}$ and $2^{\circ}$ grid (as well as a larger $5^{\circ}$ and $10^{\circ}$ grid). Figure 11. conpiled from Numbus-3 dana, indicates the fom of these global displays. This figure sumuma. rircs about 83000 dato points gathered in the ciutse of 93 Jays. The Block-5D system will provide a similar naxp covery day.

in addition tu daily glubal and hemispheric orone maps. we will be compiling monthly analyses that average data over the preceding 30-day period. These anjlyses will be published and distributed 10 interezted scientists thremghour the world at cost. Similat analyses and maps of $\mathrm{CO}_{2}$ and $\mathrm{I}_{2} \mathrm{O}$ radiance will also be provided.

In stmmary, the Satellite Orone Analysis Center will:

- Monitor the tarth's ozone vatiability froun carly 1977 intu the 1980's. establishing a bassline against which regional and global trends cun be measured.

- Provide glubal totalosone distribution data as inpat to conputer weatherandrizone amalysis and forecusting.

- Analyze uzone variability within the mesuscale (c.g., study with high-resolution satellite-ozone datid the heavily travelled North Allantic air corridor between the U.S. and leurope).

- Analyze the diumal variability of totat ozone with a two-satellite czzone-sensor system.

- Interact with the global ozone monitoring and research project of the Wurld Meteorological Organization.

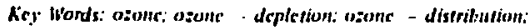

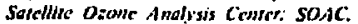




\section{Notes and Roferencos}

I. Results of thes preliminary phase were reported in C. Bender, L. Cox. Jr., and G. Chappell, An Application

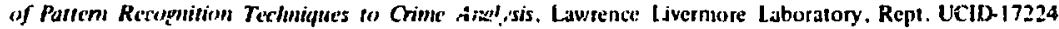
(1976).

2. L. Cox. Jr., and C. Bender, PATTER: A Polyalgurishm for the Andysis of Goneralized Data Sets, Lawrence Livermire Laburatory. Hept. UCID.16915 (1975).

3. C. Klopfenstein and C. Wilkins. Computers in Chemical and Bickinemical Rescarch (Academic Press, New York. 1972). vol. I.

4. Details of the theory and application of classification tecliniques for paltern recognition can be found in W. Meisel, Computer-Orientrd Appraches fo Aatror: Rerognition (Acidemic Press. New Yotk. 1972). 